\title{
HUBUNGAN ANTARA KUALITAS PERSAHABATAN DENGAN KEBAHAGIAAN PADA SANTRI PONDOK PESANTREN IIK RIAU
}

\section{THE RELATIONSHIP BETWEEN THE QUALITY OF FRIENDSHIP AND HAPPINESS IN SANTRI PONDOK PESANTREN IIK RIAU}

\author{
${ }^{1}$ Yuliana Intan Lestari, ${ }^{2}$ Winda Palasari \\ ${ }^{1,2}$ Fakultas Psikologi Universitas Islam Negeri Sultan Syarif Kasim \\ Riau'windaapalasarii@yahoo.com, anayuliana.psikologi@uin-suska.ac.id
}

\begin{abstract}
Introduction Santri who attend Islamic boarding schools, require them to live far apart from their parents and families. And this condition can be a barrier for these students to achieve happiness. The life of the Islamic boarding school which is different from school life in general makes it difficult for some students to adapt. In addition, the existing rules and learning programs stress the students. As a result, it makes the students depressed and stressed and has an impact on the happiness of the students. One of the factors affecting happiness is friendship. A person will be happier when experiencing high quality friendships with his friends.
\end{abstract}

Methods The purpose of this study was to examine the relationship between the quality of friendship and happiness in the students of the Imam Ibnu Katsir Islamic boarding school in Rumbai District. The sample in this study amounted to 151 people who were obtained through the quota sampling technique. The instrument used in this study was the friendship quality scale with a reliability coefficient of 0.891 and a happiness scale of 0.897. This research uses Product moment analysis technique.

Results of this study indicate a significant value of $=0.000(p \leq 0.001)$ meaning that the hypothesis is accepted, that is, there is a significant positive relationship between the quality of friendship and happiness of the students. The effective contribution of friendship quality to happiness is $7.5 \%$. This shows that the quality of friendship plays an important role in increasing happiness in students.

Conclusions and Recommendation This research concluded that quality of friendship have influence for the conquest of happiness in santri. Therefore this research that recommendation to santri for cultivate a quality friendly relationship with other person.

Keywords: friendship quality, happiness, school

\begin{abstract}
ABSTRAK
Pendahuluan Santri yang bersekolah di Pondok Pesantren, mengharuskan mereka untuk hidup jauh terpisah dari orangtua maupun keluarganya. Dan kondisi tersebut bisa menjadi penghalang untuk santri tersebut untuk mencapai kebahagiaan. Kehidupan Pondok Pesantren yang berbeda dengan kehidupan sekolah pada umumnya membuat beberapa santri sulit untuk beradaptasi. Selain itu, aturan-aturan serta program pembelajaran yang ada membuat santri tertekan. Akibatnya membuat santri tertekan dan stress serta berdampak pada kebahagiaan para santri. Salah satu faktor mempengaruhi kebahagiaan adalah persahabatan. Seseorang akan lebih bahagia saat mengalami persahabatan dengan kualitas yang tinggi dengan sahabat-sahabatnya.

Metode Tujuan penelitian ini untuk meneliti hubungan antara Kualitas Persahabatan dengan Kebahagiaan pada Santri Pondok Pesantren Imam Ibnu Katsir di Kecamatan Rumbai. Sampel dalam penelitian ini berjumlah 151 orang yang diperoleh melalui teknik kuota sampling.
\end{abstract}


Instrumen yang digunakan dalam penelitian ini adalah skala kualitas persahabatan dengan koefisien reliabilitas sebesar 0,891 dan skala kebahagiaan sebesar 0,897. Penelitian ini menggunakan teknik analisis Product moment.

Hasil Penelitian ini menunjukkan nilai signifikan sebesar $=0,000(p \leq 0,001)$ artinya hipotesis diterima, yaitu ada hubungan positif yang signifikan antara kualitas persahabatan dengan kebahagiaan pada santri. Sumbangan efektif kualitas persahabatan terhadap kebahagiaan yaitu sebesar 7,5\%. Hal ini menunjukkan bahwa kualitas persahabatan berperan penting dalam meningkatkan kebahagiaan pada santri.

Kesimpulan dan Saran Penelitian ini disimpulkan bahwa kualitas persahabatan berperan penting dalam meraih kebahagiaan pada santri. Oleh karena itu, direkomendasikan setiap santri hendaknya memupuk hubungan persahabatan yang berkualitas dengan teman.

Kata Kunci kualitas persahabatan, kebahagiaan, sekolah

\section{Pendahuluan}

Manusia dalam menjalani kehidupan selalu menginginkan hidup yang bahagia. Kebahagiaan menjadi harapan dan cita-cita terbesar bagi setiap individu dari bebagai latar belakang, usia, tempat tinggal, status sosial, maupun agama. Kebahagiaan menjadi faktor penting bagi setiap individu. Sebagaimana yang diungkapkan oleh Basya (2007) bahwa kebahagiaan merupakan suatu objek yang terus dicari manusia di setiap masa dan tempat. Sarana untuk mencapainya berbeda-beda antara satu orang dengan orang lain. Perbedaan itu sesuai dengan kepribadian masing-masing individu, keinginan dan motif , lingkungan dan kondisi eksternal dalam kehidupan individu.

Kebahagiaan dalam hidup adalah perasaan positif yang dirasakan oleh individu dalam hidupnya, yang ditandai dengan lebih banyaknya perasaan positif ada dalam diri individu daripada afek negatif. Emosi positif seperti kepercayaan diri, harapan, dan kepercayaan sangat membantu individu. Ketika individu berada dalam suasana hati yang positif, orang lain akan lebih menyukainya, berteman, dan cinta. Individu yang bahagia bersandar pada pengalaman positif yang sungguh-sungguh, yang terbebas dari ketakutan (Seligman, 2005).

Menurut Seligman (2005) bahwa orang yang bahagia memiliki kebiasaan yang lebih baik terutama berkenaan dengan kesehatan, tekanan darah yang lebih rendah, sistem kekebalan yang lebih kuat dari pada seseorang yang kurang bahagia. Orang yang bahagia mencari dan menyerap informasi tentang resiko kesehatan dan hasilnya dapat disimpulkan bahwa kebahagiaan merupakan faktor yang dapat memanjangkan usia dan meningkatkan kesehatan. Orang yang bahagia mampu menanggung rasa sakit dan melakukan langkah-langkah pencegahan masalah kesehatan.

Menurut Hurlock (1980) kebahagiaan timbul sebagai akibat dari terpenuhinya kebutuhan dan harapan. Karena kebutuhan dan harapan individu berbeda-beda, maka kebahagiaan dianggap sebagai sesuatu yang bersifat relatif, bergantung pada latar belakang budaya, jenis kelamin, serta periode dalam setiap rentang kehidupan manusia. Kebahagiaan dirasakan dan dialami oleh semua orang, termasuk juga remaja. Remaja merupakan masa peralihan dari masa kanak-kanak menuju masa dewasa. Masa remaja juga dianggap sebagai masa topan badai dan penuh dengan tantangan bagi perkembangan psikis, sebagaimana yang dinyatakan oleh Hall (dalam Santrock, 2007) bahwa masa remaja merupakan masa pergolakan yang dipenuhi oleh konflik dan perubahan suasana hati.

Usia remaja merupakan usia yang cukup berpotensi untuk memperoleh kebahagiaan, salah satu cara untuk memperoleh kebahagiaan pada remaja 
adalah melalui dukungan dan bantuan dari lingkungan keluarganya termasuk orang tua, saudara dan keluarga besar yang lainnya (Pramono, 2015). Namun di sisi lain ada sebagian remaja yang hidup jauh terpisah dari orang tua maupun keluarganya seperti yang dialami oleh santri pondok pesantren, sehingga kondisi ini bisa menjadi penghalang pada remaja tersebut untuk mencapai kebahagiaan.

Kehidupan di pondok pesantren berbeda dengan kehidupan anak pada umumnya. Di pondok pesantren, santri dituntut untuk dapat menyesuaikan diri atau beradaptasi dengan baik terhadap kegiatan dan peraturan yang berlaku di lingkungan pondok pesantren serta situasi tempat tinggal yang jauh dari orang tua (Rahmawati, 2013). Dalam penelitian yang dilakukan oleh Pritaningrum dan Wiwin (2013) kewajiban untuk tinggal di pondok pesantren menuntut santri untuk menyesuaikan diri terhadap segala aktivitas, budaya, kebiasaan yang ada di lingkungan pesantren, demi terciptanya lingkungan pesantren yang harmonis dan kondusif, pengurus pondok pesantren mewajibkan kepada para santri yang tinggal di pondok pesantren untuk menaati seluruh kegiatan dan peraturan yang berlaku di dalam pondok pesantren.

Namun, tidak sedikit santri yang merasa tertekan dengan aturan-aturan yang ada di pondok pesantren. Sebagaimana dalam penelitian yang dilakukan oleh Fadhillah (2016) pada santri sebuah pondok pesantren, bahwa banyak santri mendapatkan tekanan dengan terdapatnya aturan-aturan di dalam pondok pesantren. Selain itu, dalam penelitian yang dilakukan oleh Hendriani dan Pritaningrum (2013) keadaan di asrama dengan peraturan dan kondisi yang berbeda dengan di rumah dapat menjadi sumber tekanan (stressor) sehingga dapat menyebabkan stres. Dalam penelitian lain yang dilakukan oleh Awaliyah (2014) beberapa santri melakukan pelanggaran-pelanggaran seperti kabur dari pesantren tanpa izin dari pengurus, tidak mengikuti kegiatan wajib di pesantren, sering bolos sekolah, dan kabur dari pesantren. Hal itu disebabkan karena santri tidak bisa bebas melakukan apa yang ingin dilakukannya karena pondok pesantren memiliki tata tertib yang ketat untuk mengatur semua kegiatan santri, dan perilaku santri selama berada di pondok pesantren. Selain itu, santri yang terpaksa masuk pondok pesantren karena dorongan dari orangtuanya sering merasa tidak betah tinggal di lingkungan pesantren dengan peraturan yang ketat tetapi ia tidak mencoba untuk menyesuaikan diri dengan lingkungan di pondok pesantren.

Selain tekanan dari aturan-aturan yang ada di dalam pondok pesantren, santri juga merasa terbebani dengan program pembelajaran yang ada di pondok pesantren. Dalam penelitian yang dilakukan oleh Ramadhan (2015) beberapa santri terkadang merasa terbebani dengan program yang harus dijalankan dan membuat mereka stress.Selain itu, target hafalan yang dirasa berat bagi santri membuat santri merasa bosan dan merasa putus asa.

Kasus di atas juga dirasakan oleh santri pondok pesantren Imam Ibnu Katsir di kecamatan Rumbai Pekanbaru. Beberapa santri memutuskan untuk keluar atau berhenti bersekolah dikarenakan mereka tidak sanggup jauh dari orangtua, selain itu juga dikarenakan beberapa santri tidak sanggup mengikuti program pembelajaran yang ada di pondok pesantren tersebut. Namun, disisi lain tidak semua santri merasa tertekan dengan aturan serta program pembelajaran yang ada di pondok. Beberapa santri merasa senang untuk bersekolah dipondok pesantren. Hal tersebut dikarenakan mereka tidak ada paksaan dari orangtua mereka untuk bersekolah di pondok pesantren melainkan karena keinginan mereka sendiri. Dan selain itu, mereka juga merasa jika bersekolah di pondok pesantren bisa meningkatkan hafalan mereka terhadap AlQuran yang belum tentu didapatkan di sekolah pada umumnya. 
Permasalahan yang dirasakan oleh santri pondok pesantren tersebut diasumsikan akan dapat mempengaruhi kebahagiaan mereka. Hal ini dikarenakan menurut Ardiansyah (2014) masalah yang dihadapi oleh seorang individu secara efektif akan berdampak pada psikis, dan hal ini juga berhubungan dengan kebahagiaan yang dirasakan oleh individu tersebut. Adapun karakteristik perilaku yang muncul akibat dari permasalahan yang dihadapi yaitu dapat berupa wajah yang kurang ceria, mudah marah, dan sering mengeluh.

Dari kasus ketidakbahagiaan di atas, diketahui bahwa kebahagiaan merupakan suatu hal yang penting untuk dimiliki oleh remaja. Karena dengan adanya kebahagiaan, remaja dapat menjalani harihari dengan lebih bermakna dan terhindar dari berbagai perasaan-perasaan negatif. Remaja tidak akan melakukan hal yang merugikan dirinya bahkan orang-orang di sekitarnya. Oleh karena itu, penting kiranya untuk mengetahui faktor-faktor yang menentukan kebahagiaan seseorang. Menurut Diener (dalam Lyubomirsky, 2005) salah satu sumber yang paling penting dari kebahagiaan adalah adanya hubungan pribadi yaitu persahabatan, pernikahan, keintiman, dan dukungan sosial.

Persahabatan adalah hubungan yang melibatkan kesenangan, kepercayaan, saling mendukung, perhatian, dan spontanitas. Sebuah persahabatan dengan kualitas yang tinggi ditandai dengan tingkat perilaku menolong, keakraban, perilaku positif lainnya, serta rendahnya tingkat konflik, persaingan dan perilaku negatif lainnya (Berndt, 2002). Dalam penelitian yang dilakukan oleh Marita (2013) seseorang yang terlibat dalam kualitas persahabatan yang tinggi cenderung untuk saling berbagi, percaya, terbuka, dan mendukung, sehingga dalam hubungan ini juga akan muncul tuntutan untuk saling berkorban satu sama lain, dimana baik waktu, perhatian, maupun informasi yang dimiliki oleh seseorang harus dibagi kepada sahabatnya, begitupun sebaliknya. Dengan demikian, remaja yang memiliki kualitas persabatan yang baik akan cenderung merasa lebih bahagia.

Penelitian yang dilakukan oleh Bliezner \& Adams (dalam Demir, 2004) menunjukkan bahwa seseorang akan lebih bahagia saat mengalami persahabatan dengan kualitas yang tinggi dengan sahabat-sahabatnya. Sebuah persahabatan dengan kualitas yang tinggi ditandai dengan tingkat perilaku menolong, keakraban, perilaku positif lainnya, serta rendahnya tingkat konflik, persaingan dan perilaku negatif lainnya (Berndt, 2002).

Persahabatan dengan teman sebaya didapati memainkan peran penting pada masa remaja, terutama dalam hal memberikan dukungan sosial dan dalam rangka berbagi serta kebersamaan aktivitas. Persahabatan yang terjadi sejak kanakkanak hingga remaja berkembang dari permainan dan aktivitas yang sama-sama diminati, dari saling berbagi perasaan, emosi serta keterbukaan diri (Berndt, 2002). Dalam penelitian yang dilakukan Hayu (2015) pada mahasiswa psikologi menunjukkan bahwa adanya persahabatan yang tinggi pada mahasiswa psikologi karena di antara mahasiwa tersebut saling membutuhkan dalam bekerjasama menciptakan kelompok-kelompok tugas yang diberikan oleh dosen. Maka dari itu tugas-tugas yang diberikan oleh para dosen tersebut membuat mereka akrab satu sama lain, dan karena ada kebutuhan saling mendukung maka pada akhirnya tercipta aspek dukungan dan kepedulian (validation and caring), yakni saling mendukung agar tugas kelompok cepat selesai, bantuan dan bimbinga (help and guidance), yakni saling membantu agar tugas kelompok cepat selesai, dan pemecahan masalah (conflict resolution) yakni saling memberi solusi terdahap masalah dalam tugas tersebut sebagai aspek dari persahabatan.

Kebahagiaan yang dirasakan oleh mahasiwa berada dalam kategori sedang, karena mungkin kebahagiaan yang mereka alami tidak hanya dipengaruhi oleh persahabatan yang tinggi dialami mereka, 
namun juga bisa dialami oleh faktor lainnya.Dan disebabkan tingkat persahabatan yang tinggi pada mahasiswa psikologi dalam penelitian, maka mempengaruhi pula tingkat kebahagiaan pada mahasiswa tersebut yakni dalam kategori sedang.

Dalam penelitian yang dilakukan oleh Herawaty (2015) mengenai "Penerimaan teman sebaya dengan kebahagiaan pada remaja", hasil penelitian menunjukkan bahwa terdapat korelasi yang positif antara penerimaan teman sebaya dengan kebagaiaan pada remaja. Hasilnya menunjukkan bahwa skor kebahagiaan (40\%) pada remaja berada pada kategori sedang, sehingga dapat disimpulkan bahwa jika remaja diterima oleh teman-teman sebayanya, maka akan dapat membuat remaja merasa bahagia dan jauh dari perasaan sedih maupun kesepian. Hal ini disebabkan karena penerimaan teman sebaya membuat remaja merasa diakui dan diperhatikan keberadaannya oleh temanteman sebayanya.

Penelitian lain yang dilakukan oleh Hayu (2015) menunjukkan bahwa persahabatan mempengaruhi kebahagiaan pada remaja. Semakin tinggi persahabatan yang dialami remaja, maka semakin tinggi pula kebahagiaan yang dirasakan remaja.Begitu juga sebaliknya, semakin rendah persahabatan yang dialami remaja, maka semakin rendah pula kebahagiaan yang dirasakan remaja tersebut.

Berdasarkan fenomena yang telah diuraikan di atas, peneliti menganggap bahwa penelitian ini perlu dilakukan, mengingat penelitian yang membahas tentang kaitan antara kualitas persahabatan dengan kebahagiaan pada remaja pondok pesantren masih belum banyak dilakukan. Maka peneliti tertarik untuk melakukan penelitian secara ilmiah dengan judul "Hubungan antara Kualitas Persahabatan dengan Kebahagiaan pada santri Pondok Pesantren Imam Ibnu Katsir di Kecamatan Rumbai Riau".

\section{Metode}

Jenis penelitian yang digunakan dalam penelitian ini adalah penelitian kuantitatif dengan menggunakan pendekatan korelasional. Populasi pada penelitian ini adalah siswa/i MTS kelas VII, VII dan IX pondok pesantren Imam Ibnu Katsir di kecamatan Rumbai, sebanyak 258 orang. Sampel adalah bagian dari jumlah dan karakteristik yang dimiliki oleh populasi (Sugiyono,2013). Teknik pengambilan sampel dalam penelitian ini menggunakan teknik Kuota sampling. Sampel yang digunakan dalam penelitian ini adalah santri MTS kelas VII dan VIII di Pondok Pesantren Imam Ibnu Katsir di Kecamatan Rumbai. Penelitian ini menggunakan skala Friendship Quality Questionnare (FQQ) dari Parker dan Asher (1993). Skala ini terdiri dari enam aspek kualitas persahabatan yaitu dukungan dan kepedulian (validation and caring), konflik dan penghianatan (conflict and betrayal), pertemanan dan rekreasi (companionship and recreation), bantuan dan bimbingan (help and guidance), pertukaran yang akrab (intimate and change), pemecahan masalah (conflict resolution.

Skala yang digunakan untuk mengukur kebahagiaan adalah skala SAPAN yang terdiri atas 20 afek, yaitu 10 afek positif dan 10 afek negatif. Setiap afek dijawab dengan memilih salah satu dari lima alternatif jawaban yang menunjukkan intensitas afek yang dirasakan pada saat kini, yaitu sangat lemah atau tidak sama sekali diberi skor 1, lemah diberi skor 2, sedang diberi skor 3, agak kuat diberi skor 4, dan sangat kuat diberi skor 5 .

Data yang diperoleh pada penelitian ini selanjutnya akan dianalisis dengan menggunakan teknik korelasi Product Moment dari Pearson yang dihitung dengan menggunakan bantuan program SPSS (Statistical of Package for Social Science) versi 24.0. Data hasil pengukuran kualitas persahabatan dikorelasikan dengan data kebahagiaan. Data tersebut kemudian akan dianalisis dengan menggunakan teknik analisis korelasi product moment. 


\section{Hasil}

Uji normalitas dilakukan untuk mengetahui normal atau tidaknya sebaran data penelitian. Adapun salah satu bentuk uji normalitas yang sering digunakan adalah teknik one sample kolmogrovo-smirnov. Berdasarkan teknik uji normalitas tersebut, maka menurut Idrus (2009) data baru dikatakan normal apabila signifikansi lebih besar dari 0,05 ( $p>0,05)$. Berdasarkan hasil uji normalitas, diperoleh signifikansi pada variabel kualitas persahabatan dan kebahagiaan seperti yang tertera pada tabel berikut:

Tabel 1. Hasil Uji Normalitas

\begin{tabular}{|c|c|}
\hline $\begin{array}{l}\text { Kolmogrovo- } \\
\text { smirnov }\end{array}$ & Signifikansi (p) \\
\hline $\begin{array}{l}\text { Kualitas } \\
\text { persahabatan }\end{array}$ & Normal \\
\hline Kebahagiaan & Normal \\
\hline $\begin{array}{l}\text { Berdasarkan tabel } 1 \text { dapat diketahui } \\
\text { bahwa signifikansi untuk kedua variabel } \\
\text { ebih besar dari } 0,05(\mathrm{p}=0,391>0,05 \text { untuk } \\
\text { kualitas persahabatan dan } \mathrm{p}=0,570>0,05 \\
\text { untuk kebahagiaan). Dengan demikian } \\
\text { dapat disimpulkan sebaran data kedua } \\
\text { variabel dalam penelitian ini dinyatakan } \\
\text { tormal.Berdasarkan uji linieritas pada }\end{array}$ & $\begin{array}{l}\text { variabel kualitas persahabatan dan variabel } \\
\text { kebahagiaan yang diperoleh dengan } \\
\text { menggunakan bantuan program SPSS17.0 } \\
\text { for windows, diketahui F sebesar } 13,206 \\
\text { dengan taraf signifikansi } 0,000 \text {. Karena } \\
\text { taraf signifikansi yang diperoleh dari } \\
\text { penelitian adalah } 0,000 \text { dan lebih kecil } \\
\text { daripada } 0,05 \text { (p } ₫ 0,05) \text {, maka data dapat } \\
\text { dikatakan linier. }\end{array}$ \\
\hline
\end{tabular}

Tabel 2. Hasil Uji Linearitas

\begin{tabular}{lccc}
\hline \multicolumn{1}{c}{ Variabel } & F & Signifikansi (p) & Keterangan \\
\hline $\begin{array}{l}\text { Kualitas persahabatan } \\
\text { kebahagiaan }\end{array}$ & 13,206 & 0,000 & Linier \\
\hline
\end{tabular}

Pada penelitian ini telah dilakukan uji hipotesis yang bertujuan untuk mengetahui taraf signifikansi hubungan antara kualitas persahabatan dengan dengan kebahagiaan.Adapun ketentuan diterima atau ditolaknya sebuah hipotesis apabiladi signifikansi di bawah atau sama dengan $0,05$ ( $\mathrm{p} \leq 0,05)$, maka hipotesis diterima (Sugiyono, 2013).

Berdasarkan hasil analisis terhadap data penelitian, maka diperoleh nilai signifikansi (P) yaitu 0,001 dan nilai tersebut lebih kecil dari 0,05 ( $\mathrm{p} \leq 0,05)$. Nilai koefisiensi korelasi (r) yang diperoleh sebesar 0,275 dan bertanda positif (+) yang berarti terdapat arah hubungan yang positif. Hal ini sejalan dengan hipotesis peneliti yang menyebutkan ada hubungan positif. Dengan demikian, sesuai dengan ketentuan penerimaan atau penolakan hipotesis seperti yang telah dikemukakan di atas, maka hipotesis diterima.

Tabel 3. Hasil Uji Hipotesis

\begin{tabular}{ccc}
\hline \multicolumn{1}{c}{ Variabel } & R & Sig. \\
\hline $\begin{array}{l}\text { Kualitas persahabatan } \\
\text { kebahagiaan }\end{array}$ & 0,275 & 0,001 \\
\hline $\begin{array}{c}\text { Berdasarkan skala kualitas } \\
\text { persahabatan, subjek dapat dikategorikan } \\
\text { dalam tiga kategori, yaitu rendah, sedang, }\end{array}$ & $\begin{array}{l}\text { dan tinggi. Diharapkan skor pada penelitian } \\
\text { ini dapat memberikan gambaran yang jelas. } \\
\text { Skala variabel Kualitas Persahabatan }\end{array}$
\end{tabular}


terdapat 31 aitem, sehingga nilai terendah yang mungkin diperoleh adalah $1 \times 31=31$, sedangkan nilai tertinggi yang mungkin diperoleh adalah 4 x31 = 124, rentang skor (range) adalah $124-31=93$, skor rata-rata (mean) adalah $(124+31) / 2=77,5$, dan standar deviasinya $(124-31) / 6=15,5$.

Tabel 4. Kategorisasi Kualitas Persahabatan

\begin{tabular}{|c|c|c|c|}
\hline Kategorisasi & Nilai & Frekuensi & Persentase $(\%)$ \\
\hline Rendah & $X \leq 62$ & 3 & $2 \%$ \\
\hline Sedang & $62<X \leq 93$ & 85 & $56,3 \%$ \\
\hline Tinggi & $93 \leq X$ & 63 & $41,7 \%$ \\
\hline \multicolumn{2}{|c|}{ Jumlah } & 151 & $100 \%$ \\
\hline
\end{tabular}

Berdasarkan tabel kategorisasi secara keseluruhan, kategorisasi subjek pada skala kualitas persahabatan berada pada kategori rendah dengan frekuensi 3 orang (2\%), subjek yang berada pada kategori sedang dengan frekuensi 85 orang $(56,3 \%)$, dan subjek yang berada pada kategori tinggi dengan frekuensi 63 orang $(41,7 \%)$. Dengan demikian dapat disimpulkan bahwa kualitas persahabatan pada remaja pondok pesantren berada pada kategori sedang, maka dapat diartikan bahwa rata-rata subjek memiliki kualitas persahabatan yang sedang.

Tabel 5. Kategorisasi Variabel Kebahagiaan

\begin{tabular}{|c|c|c|c|}
\hline Kategorisasi & Nilai & Frekuensi & Persentase $(\%)$ \\
\hline Rendah & $X \leq 42$ & 2 & $1,3 \%$ \\
\hline Sedang & $42<X \leq 68$ & 133 & $88,1 \%$ \\
\hline Tinggi & $68 \leq X$ & 16 & $10,6 \%$ \\
\hline \multicolumn{2}{|c|}{ Jumlah } & 151 & $100 \%$ \\
\hline
\end{tabular}

Berdasarkan tabel kategorisasi di atas menunjukkan bahwa kategori subjek pada skala kebahagiaan berada pada kategori rendah dengan frekuensi 2 orang $(1,3 \%)$, subjek yang berada pada kategori sedang dengan frekuensi 133 orang $(88,1 \%)$, subjek yang berada pada kategori tinggi dengan frekuensi 16orang (10,6\%). Dengan demikian dapat disimpulkan bahwa kebahagiaan pada remaja pondok pesantren
Berdasarkan skala kebahagiaan, subjek dapat dikategorikan dalam lima kategori, yaitu rendah, sedang, dan tinggi. Diharapkan skor pada penelitian ini dapat memberikan gambaran yang jelas. Skala variabel Kebahagiaan terdapat 18 aitem, sehingga nilai terendah yang mungkin diperoleh adalah $1 \times 18=18$, sedangkan nilai tertinggi yang mungkin diperoleh adalah $5 \times 18=90$, rentang skor (range) adalah 90$18=72$, skor rata-rata (mean) adalah $(90+18) / 2=54$, dan standar deviasinya (90$18) / 6=12$. berada pada kategori sedang, maka dapat diartikan bahwa subjek memiliki kebahagiaan yang sedang.

Aspek-aspek dari kualitas persahabatan yaitu dukungan dan kepedulian, konflik dan penghianatan, pertemanan dan rekreasi, bantuan dan bimbingan, pertukaran yang akrab, pemecahan masalah. Berdasarkan hasil korelasi pada setiap aspek kualitas 
persahabatan terhadap kebahagiaan dapat dilihat koefisien korelasi (R) dan $R$ square yang merupakan persentase sumbangsih setiap aspek kualitas persahabatan terhadap kebahagiaan. Berikut rinciannya:

Tabel 6. Analisis hubungan aspek kualitas persahabatan dan kebahagiaan

\begin{tabular}{lcccccc}
\hline \multicolumn{1}{c}{ Aspek } & Mean & SD & r & P & Rsquare & Ket. \\
\hline $\begin{array}{l}\text { Dukungan dan } \\
\text { kepedulian }\end{array}$ & 26,43 & 3,932 & 0,249 & 0,002 & 0,062 & Signifikan \\
$\begin{array}{l}\text { Konflik dan } \\
\text { penghianatan }\end{array}$ & 15,63 & 2,741 & 0,364 & 0,000 & 0,132 & Signifikan \\
$\begin{array}{l}\text { Pertemana dan } \\
\text { rekreasi }\end{array}$ & 8,31 & 1,848 & 0,139 & 0,088 & 0,019 & $\begin{array}{c}\text { Tidak } \\
\text { Signifikan }\end{array}$ \\
$\begin{array}{l}\text { Bantuan dan } \\
\text { bimbangan }\end{array}$ & 21,52 & 2,941 & 0,163 & 0,000 & 0,027 & Signifikan \\
$\begin{array}{l}\text { Pertukaran yang } \\
\text { akrab }\end{array}$ & 10,83 & 2,378 & 0,002 & 0,978 & 0,000 & $\begin{array}{c}\text { Tidak } \\
\text { Pemecahan }\end{array}$ \\
\begin{tabular}{l} 
Masalah \\
\hline
\end{tabular} & 9,08 & 1,557 & 0,239 & 0,003 & 0,057 & Signifikan \\
\hline
\end{tabular}

Berdasarkan hasil analisis tabel 6 menunjukkan bahwa aspek konflik dan penghianatan merupakan aspek yang memiliki nilai sumbangsih paling tinggi dengan nilai $\mathrm{R}$ square sebesar 0,132 pada variabel kualitas persahabatan, artinya rendahnya tingkat konflik dan penghianatan pada santri membuat santri menghindari perbedaan argumen, perselisihan, rasa kesal serta ketidakpercayaan satu sama lain. Sehingga dengan rendahnya tingkat konflik dan penghianatan di dalam persahabatan dapat membuat santri menjadi lebih bahagia.

\section{Pembahasan}

Hasil penelitian menunjukkan bahwa terdapat hubungan antara kualitas persahabatan dengan kebahagiaan pada remaja pondok pesantren. Berdasarkan perhitungan dengan menggunakan analisis korelasi Product Moment and Service Solution (SPSS) 24.00 for windows maka diperoleh koefisien korelasi (r) sebesar 0,275 dengan taraf signifikansi $\mathrm{p}=0,000$ (p $₫, 01$ ). Hal tersebut menunjukkan bahwa ada hubungan positif yang signifikan antara kualitas persahabatan dengan kebahagiaan pada remaja pondok pesantren.Dengan demikian, hipotesis dalam penelitian ini diterima.

Hasil penelitian ini didukung oleh penelitian yang dilakukan oleh Astuti (2016) yang berjudul hubungan antara religiusitas dan kualitas persahabatan dengan kebahagiaan pada remaja panti asuhan. Berdasarkan analisis data yang telah dilakukan mengenai kebahagiaan, bahwa terdapat korelasi positif yang signifikan antara kualitas persahabatan dengan kebahagiaan pada remaja. Dalam penelitian yang dilakukan oleh Cheng dan Furham (dalam Hayu, 2015) persahabatan dengan teman sebaya juga akan menjadi penting bagi kebahagiaan seorang remaja, karena remaja tersebut mendapatkan manfaat berupa dukungan sosial, berbagi dan menikmati permainan serta aktivitas yang sama-sama diminati serta mendapat umpan balik yang positif.

Hasil penelitian menunjukkan bahwa variabel kualitas persahabatan memiliki kontribusi sebesar $7,5 \%$ terhadap kebahagiaan pada remaja pondok pesantren, sedangkan sisanya 92,5\% dipengaruhi oleh faktor-faktor lain. Faktor-faktor lain yang dapat mempengaruhi kebahagiaan meliputi uang, emosi positif, usia, agama, kesehatan, 
pendidikan, kehidupan sosial, dan pernikahan (Seligman, 2005).

Sahabat merupakan area terpenting dalam dunia remaja, dan dalam masa transisinya remaja menghabiskan sebagaian besar waktunya dengan sahabat-sahabatnya. Pada masa ini, sikap remaja terhadap teman mulai berubah. Remaja mulai mengenali kebutuhan akan teman atau sahabat yang sesuai dengan dirinya. Hal ini tercermin dalam menentukan teman, jumlah teman, kualitas hubungan dan keinginan untuk menentukan teman sejenis maupun lawan jenis (Hurlock, 1980).

Dalam penelitian Marita (2013) dikatakan bahwa seseorang yang terlibat dalam kualitas persahabatan yang tinggi cenderung untuk saling berbagi, percaya, terbuka, dan mendukung, sehingga dalam hubungan ini juga akan muncul tuntutan untuk saling berkorban satu sama lain. Pengorbanan satu sama lain ini yaitu baik waktu, perhatian, maupun informasi yang dimiliki oleh seseorang harus dibagi kepada sahabatnya, begitupun sebaliknya. Dengan demikian, remaja yang memiliki kualitas persahabatan yang baik akan cenderung merasa lebih bahagia. Hal ini selaras dengan pernyataan Seligman, yang mengemukakan bahwa kebahagiaan merupakan keadaan seseorang yang berada dalam perasaan positif yaitu dengan banyaknya afek positif yang dirasakan seseorang, dibandingkan dengan afek negatif. Dan sebaliknya, orang yang tidak bahagia lebih banyak merasakan afek negatif, dibandingkan dengan afek positif (Seligman, 2005).

Remaja pondok pesantren Imam Ibnu Katsir memiliki tingkat kategorisasi kebahagiaan yang sedang dengan persentase sebesar $88,1 \%$. Hal ini mengindikasikan bahwa remaja pondok pesantren imam ibnu katsir memiliki lebih banyak afek positif didalam dirinya daripada afek negatif. Hal ini sejalan dengan pendapat Seligman (2005) yang menyatakan bahwa individu yang bahagia adalah individu yang lebih banyak merasakan afek positif dari pada afek negatif dalam dirinya.Hasil analisis dimensi afek positif $78,1 \%$ dengan jumlah 118 orang dalam kategori sedang dan dimensi afek negatif $79,5 \%$ dengan jumlah 120 orang dalam kategori sedang.

Sementara itu, remaja pondok pesantren Imam Ibnu Katsir juga memiliki kualitas persahabatan yang dikategorisasikan sedang, yaitu sebesar $56,3 \%$. Artinya, remaja pondok pesantren imam ibnu katsir memiliki dukungan, minat dan kepedulian terhadap satu sama lain, adanya upaya dalam menyelesaikan masalah, adanya bantuan dan bimbingan satu lain dalam menghadapi tugas-tugas rutin sekolah, adanya keakraban satu sama lain untuk bertukar informasi dan perasaan, serta rendahnya konflik dan penghianatan satu sama lain. Hal ini sejalan dengan pendapat Berndt (2002) bahwa sebuah persahabatan dengan kualitas persahabatan yang tinggi ditandai dengan tingkat perilaku menolong, keakraban, dan perilaku positif lainnya, serta rendahnya tingkat konflik, persaingan dan perilaku negatif lainnya. Kualitas persahabatan juga memiliki perngaruh langsung dalam mempengaruhi sikap dan perilaku karena dengan kualitas persahabatan yang tinggi dapat mengurangi rasa malu serta isolasi diri.

Berdasarkan hasil analisis aspek kualitas persahabatan terhadap kebahagiaan menunjukkan bahwa aspek konflik dan penghianatan merupakan aspek yang memiliki nilai sumbangsih paling tinggi dengan nilai $R$ square sebesar 0,132 pada variabel kualitas persahabatan, artinya rendahnya tingkat konflik dan penghianatan pada santri membuat santri menghindari perbedaan argumen, perselisihan, rasa kesal serta ketidakpercayaan satu sama lain. Sehingga dengan rendahnya tingkat konflik dan penghianatan didalam persahabatan dapat membuat santri menjadi lebih bahagia. Sebagaimana menurut Bertndt (2002), sebuah persahabatan dengan kualitas yang tinggi ditandai dengan tingkat perilaku menolong, keakraban, perilaku positif lainnya, serta rendahnya tingkat 
konflik, persaingan dan perilaku negatif lainnya.

\section{Kesimpulan dan Saran}

Berdasarkan penelitian yang telah dilakukan, maka dapat diambil kesimpulan, yaitu terdapat hubungan yang signifikan antara kualitas persahabatan dengan kebahagiaan pada santri pondok pesantren Imam Ibnu Katsir di Kecamatan Rumbai. Kontribusi yang diberikan variabel kualitas persahabatan berdasarkan korelasi Product Moment sebesar 7,5\% dansisanya $92,5 \%$ dipengaruhi oleh faktor lainnya. Berdasarkan hasil analisis aspek kualitas persahabatan terhadap kebahagiaan menunjukkan bahwa aspek konflik dan penghianatan merupakan aspek yang memiliki nilai sumbangsih paling tinggi dengan nilai $\mathrm{R}$ square sebesar 0,132 pada variabel kualitas persahabatan, artinya rendahnya tingkat konflik dan penghianatan pada santri membuat santri menghindari perbedaan argumen, perselisihan, rasa kesal serta ketidakpercayaan satu sama lain. Sehingga dengan rendahnya tingkat konflik dan penghianatan didalam persahabatan dapat membuat santri menjadi lebih bahagia. Bentuk hubungan kualitas persahabatan dengan kebahagiaan pada santri pondok pesantren Imam Ibnu Katsir adalah positif. Dengan kata lain, semakin tinggi kualitas persahabatan yang dimiliki oleh santri, maka semakin tinggi kebahagiaan yang dirasakan oleh santri.

\section{Daftar Pustaka}

Alawiyah, Iyum Tsamratul Ainil. (2014). Program Bimbingan Pribadi-Sosial untuk Mengembangkan Penyesuaian Diri Santri. Skripsi. Fakultas Ilmu Pendidikan: Universitas Pendidikan Indonesia.

Ardiansyah, Atrof. (2014). Hubungan antara Dukungan Teman Sebaya dengan Kebahagiaan pada Mahasiswa Fakultas Psikologi UIN Suska Riau. Skripsi. UIN Suska Riau.
Astuti, Linda. (2016). Hubungan antara Religiusitas dan Kualitas Persahabatan dengan Kebahagiaan pada Remaja Panti Asuhan di Pekanbaru. Skripsi. Pekanbaru: Universitas Islam Negeri Sultan Syarif Kasim Riau.

Azwar, S. (2009). ReliabilitasdanValiditas. Yogyakarta: PustakaPelajar.

Azwar, S. (2012). Penyusunan Skala Psikologi. Yogyakarta: Pustaka Pelajar.

Azwar, S. (2015). Penyusunan Skala Psikologi Edisi 2. Yogyakarta: Pustaka Pelajar.

Baron, R.A, \& Byrne, D. (2005). Psikologi Sosial (jilid 2). Jakarta: Erlangga.

Basya, S.H. (2007). Kamus Mini Hidup Bahagia. Jakarta: Cakrawala.

Berndt, J. (2002). Journal Friendship Quality and Social Development. Jurnal. 1,7-10.

Demir, M, \&Urberg, K. (2004). Friendship And Adjustment Among Adolescence. Journal Experimental Child Psychology.

Fadhillah, Erdo Primada Akhmad. (2016). Hubungan antara Psychological Well-Being dan Happiness pada Remaja di Pondok Pesantren. Jurnal Ilmiah Psikologi. Universitas Gunadarma. Vo. 09 No. 01.

Hayu, Erlinda. (2015). Hubungan antara Persahabatan dengan Keabahagiaan pada Remaja. Naskah Publikasi. Fakultas Psikologi Universitas Muhammadiyah Surakarta.

Herawaty, Yulia. (2015). Hubungan Antara Penerimaan Teman Sebaya Dengan Kebahagiaan Pada Remaja. Jurnal Psikologi Universitas Islam Riau.Vol. 09 No. 03.

Hurlock, Elizabeth B. (1980). Psikologi Perkembangan. Suatu Pendekatan Sepanjang Rentang Kehidupan. Jakarta: Erlangga. 
Lyubomirsky, C.T. (2005). Journal. Review Of Research Challenge. Psychology Bulletin. Vol. 131 No. 6

Marita, Nelda. (2013). Hubungan antara Kualitas Persahabatan dengan Kebahagiaan pada Remaja. Skripsi. Universitas Sultan Syarif Kasim Riau.

Mundzir, Mohamad, F. (2016). Religiusitas Dan Kebahagiaan Pada Santri Pondok Pesantren. Skripsi. Yogyakarta: Universitas Islam Negeri Sunan Kalijaga.

Santrock, Jhon W. (2007). Adolescence: Perkembangan Remaja. Jakarta: Erlangga.

Parker, Jeffrey G \&Steveen R. Asher. (1993). Friendship and Frienship Quality in Middle Childhood: Links With Peer Group Acceptence and Feelings of Loneliness and Social Dissatisfaction. Journal Of Developmental Psychology. Vol. 29, No. 04.

Pramono, Joko Beni. (2015). Perbedaan Kebahagiaan Remaja Panti Asuhan Umar Bin Khottob Bantul Yogyakarta Ditinjau dari Jenis Kelamin. Skripsi. Fakultas Ilmu Sosial dan Humanoria: UIN Sunan Kalijaga Yogyakarta.
Pritaningrum, Meidiana \& Wiwin Hendriani.(2013). Penyesuaian Diri Remaja yang Tinggal di Pondok Pesantren Modern NurulIzzah Gresik pada tahun Pertama. Jurnal Psikologi Kepribadian dan Sosial. Universitas Airlangga. Vol. 02 No. 03.

Ramadhan, Yoga Achmad. (2012). Kesejahteraan Psikologis pada Remaja Santri Pengahafal Al-Quran. Universitas Muhammadiyah Malang.Vol. 02 No. 01.

Rahmawati, Anita. (2013). Peer Group sebagai Wadah Penyesuaian Diri Remaja di Lingkungan Pondok Pesantren Modern. Naskah Publikasi. Fakultas Psikologi Universitas Muhammadiyah Surakarta.

Seligman, Martin E.P. (2005). Authentic Happiness: Menciptakan Kebahagiaan dengan Psikologi Positif (terjemahan). Bandung: PT MizanPustaka.

Sugiyono.(2012). Statistika Untuk Penelitian. Bandung: Alfabeta.

Sugiyono. (2013). Metode Penelitian Kuantitatif, Kualitatifdan $R$ \& D. Bandung: Alfabet. 